\title{
Illustrating school-to-work transition through drawings: An exploratory study with a sample of South African students
}

\begin{tabular}{|c|c|}
\hline \multicolumn{2}{|c|}{$\begin{array}{l}\text { Authors: } \\
\text { Tinashe Harry }{ }^{1} \text { (D) } \\
\text { Willie T. Chinyamurindi }{ }^{2}\end{array}$} \\
\hline \multicolumn{2}{|c|}{$\begin{array}{l}\text { Affiliations: } \\
{ }^{1} \text { Department of Industrial } \\
\text { Psychology, University of Fort } \\
\text { Hare, Alice, South Africa }\end{array}$} \\
\hline \multicolumn{2}{|c|}{$\begin{array}{l}{ }^{2} \text { Department of Business } \\
\text { Management, University of } \\
\text { Fort Hare, East London, } \\
\text { South Africa }\end{array}$} \\
\hline \multicolumn{2}{|c|}{$\begin{array}{l}\text { Corresponding author: } \\
\text { Willie Chinyamurindi, } \\
\text { chinyaz@gmail.com }\end{array}$} \\
\hline \multicolumn{2}{|c|}{$\begin{array}{l}\text { Dates: } \\
\text { Received: } 19 \text { Aug. } 2019 \\
\text { Accepted: } 17 \text { June } 2020 \\
\text { Published: } 03 \text { Sept. } 2020\end{array}$} \\
\hline \multicolumn{2}{|c|}{$\begin{array}{l}\text { How to cite this article: } \\
\text { Harry, T., \& } \\
\text { Chinyamurindi, W.T. (2020). } \\
\text { Illustrating school-to-work } \\
\text { transition through drawings: } \\
\text { An exploratory study with } \\
\text { a sample of South African } \\
\text { students. SA Journal of } \\
\text { Human Resource } \\
\text { Management/SA Tydskrif vir } \\
\text { Menslikehulpbronbestuur, } \\
\text { 18(0), a1272. https://doi.org/ } \\
\text { 10.4102/sajhrm.v18i0.1272 }\end{array}$} \\
\hline \multicolumn{2}{|c|}{$\begin{array}{l}\text { Copyright: } \\
\text { C 2020. The Authors } \\
\text { Licensee: AOSIS. This } \\
\text { is licensed under the } \\
\text { Creative Commons } \\
\text { Attribution License. }\end{array}$} \\
\hline \multicolumn{2}{|l|}{ Read online: } \\
\hline 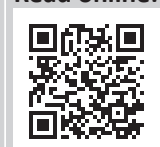 & $\begin{array}{l}\text { Scan this QR } \\
\text { code with your } \\
\text { smart phone or } \\
\text { mobile device } \\
\text { to read online. }\end{array}$ \\
\hline
\end{tabular}

Orientation: Unemployment is a matter of great concern within the South African context.

Research purpose: The purpose of this study was to explore the experiences of students who are in preparation to enter the labour market, to generate data about students' experiences of being unemployed and to explore the usefulness of diagrams as a data generation tool in exploring such experiences.

Motivation for the study: There is need to understand transition experiences of unemployed youths in South Africa and the basis for making interventions.

Research approach/design and method: A qualitative research approach utilising a participatory research design technique was used.

Main findings: Three main drawings are illustrated that express students' concern regarding this transition. These drawings heighten the focus on (1) individual evaluation of students as they make the transition, (2) evaluation of the university enrolment experience and (3) students' concern about their future, albeit the high unemployment rate in South Africa.

Managerial/practical implications: Through the reflections from the drawings, suggestions are made to assist researchers, career counsellors and students.

Contribution/value-addition: This article contributes to the literature on the use and need of using the visual methodology as a part of data generation, especially when working with vulnerable students.

Keywords: drawings; career; unemployment; students; participatory visual method.

\section{Introduction}

South Africa is currently facing a high unemployment rate. This challenge is noted to affect mostly students and those with little or no skills that can be integrated into the job market (Fox, Senbet, \& Simbanegavi, 2016; Tomlinson \& Holmes, 2017). Different causes of this high rate of unemployment are widely documented. Some argue the challenge to be influenced by a failing educational system (Irwin, Mader, \& Flynn, 2018) facing quality issues (Frick, 2018). Others (e.g. Graham \& Da Lannoy, 2016; Walker \& Fongwa, 2017) confine the challenge of unemployment in South Africa to be because of the social inequality that characterises the country (Harry, Chinyamurindi, \& Mjoli, 2018). The role of the apartheid regime and its policy of racial separation is also argued to be affecting the issue of skills within the South African context (Chinyamurindi, 2012, 2016; Walton, 2018). Despite many young people in post-apartheid South Africa having access to higher education (Musitha \& Mafukuta, 2018) and better job prospects (Aida, Norailis, \& Rozaini, 2015), unemployment and an unequal society are still prevalent (Dunga, 2016; Mok, 2016).

Within such a context, there is a need to understand the needs of different stakeholders, such as students, as they make the transition into the world of work (Irwin et al., 2018). Furthermore, career counsellors can use information from such stakeholders in assisting them to address challenges regarding employability faced by students (Scott, 2018) and propose interventions deemed to be useful not only for students, but also for their families, potential employers and, finally, the higher education system (Maree, 2018). Institutions of higher learning must be seen to be playing a strategic role in assisting nations in enhancing the employability of students and graduates (Lourens, 2016; Von Möllendorff, Kurgat, \& Speck, 2017). Shivoro, Shalyefu and Kadhila (2018) concede to this and attribute institutions of higher learning to be tasked with 
preparing a labour force with a relevant skills set. Graduates from higher education institutions are reported not to always have the necessary skills or capabilities (Scott, 2018). The concern however is not only how under-prepared graduates are, but also the lack of an understanding of their needs in view of the macro-economic challenges (Dunga, 2016; Schoër, Rankin, \& Roberts, 2014).

\section{Unemployment in South Africa}

The number of unemployed youths in the world is a cause of great concern amongst policymakers. The situation is no different in South Africa as many youths are facing high rates of unemployment. In South Africa, the youth unemployment rate is high regardless of the educational level. It has been noted that youth unemployment in South Africa is caused by several factors, but one of the major causes is skills mismatch (Graham, Williams, \& Chisoro, 2019). The labour market is consisted of work seekers who lack relevant skills because of the poor education system in the country. There is a significant rise in the unemployment rate in South Africa, especially affecting young people (Statistics South Africa, 2019).

An increase in access to higher education has resulted in a growing labour force. However, the system is failing to create employment opportunities to absorb all the graduates. The demand for employment surpasses the supply thereof. The inability to reduce the unemployment rate over the past few years is of great concern for the country. Statistics South Africa (2019) reported that the unemployment rate amongst young graduates is on the rise. A high number of unemployed youths have limited access to quality education and opportunities in the labour market. The issues can also be because of the skills needed in the labour market. WakelinTheron, Ukpere and Spowart (2018) using the tourism context highlighted not only the importance but also critical shortage of skills sets, such as customer service or awareness, ethical conduct at work, verbal communication, acceptance of responsibility, attention to detail, ability to work under pressure, time management skills and, finally, motivation skills.

There is little consensus about graduate unemployment as a challenge in South Africa. Some studies have suggested that graduate unemployment is not a challenge as graduates face low unemployment rates when compared in parallel to their non-graduate counterparts (Van Der Berg, Van Broekhuizen, \& Hofmeyr, 2016; Van Der Berg \& Van Broekhuizen, 2012). Other studies, however, have shown that graduate unemployment has been increasing over the past few years (Pauw, Oosthuizen, \& Van Der Westhuizen, 2008; Reddy, 2016; Van de Rheede, 2012). According to some studies, non-graduates face a $55 \%$ probability of unemployment, whilst graduates have an $8 \%$ possibility of being unemployed (Van Der Berg et al., 2016; Van Der Beg \& Hendrik, 2012). It is important to keep in mind that South African graduates are not a homogeneous group despite low levels of graduate unemployment rate. Different groups of graduates experience the labour market differently and their transitions into the labour market have marked differences. Studies have shown that some graduates experience chronic unemployment, whilst others secure employment soon after graduation (Kraak, 2010). The highest unemployment rates were noted amongst black Africans $(30.4 \%)$ as compared to white Africans (7.6\%). The literature on graduate unemployment has often disregarded these distinctions.

Studies have indicated that employment outcomes of graduates are shaped by race. To date, several studies have found that white graduates are more likely to be employed than black graduates (e.g. Baldry, 2016; Mncayi \& Dunga, 2016; Rogan et al., 2015). In the same vein, studies have indicated that black graduates face high rates of unemployment and chronic unemployment in comparison to their white counterparts (Baldry, 2016; Mncayi \& Dunga, 2016). Other studies have highlighted that differential employment rates between black and white graduates were caused by discrimination in the recruitment process as employers favour hiring white graduates (Kraak, 2010). There is a stream of work that suggests that extended periods of unemployment can result in negative consequences for the individuals, such as social exclusion, loss of revenue for governments, increase in public spending and mental illnesses (Branson et al., 2019; Henderson et al., 2017). Many obstacles amongst the youths in South Africa result in the perpetuation of inter-generational inequalities.

It has been argued that there is a perceived difference between the quality of education received by white and black graduates. Most of the black graduates attended socioeconomically disadvantaged schools that are perceived to be of poor quality by employers (Pauw et al., 2006). Bhorat, Mayet and Visser (2010) noted that black graduates face high unemployment mostly because of their race rather than the nature of the qualification or type of institution.

The other reason for varying employment outcomes for white and black graduates is the job search strategies employed. Evidence suggests that black graduates, because of a lack of social capital, rely on ineffective traditional methods, whilst white graduates depend on social capital to obtain employment (Rogan et al., 2015). Baldry (2016) demonstrated that unemployment was prone to graduates from rural areas, low socio-economic backgrounds and those who lived in households with unemployed members.

The labour market outcomes of graduates are also shaped by the type of institution they come from. Studies have found that graduates from historically advantaged institutions (HAIs) have better employment prospects than their counterparts from historically disadvantaged institutions (HDIs) who take longer time to obtain an employment (Oluwajodu, Blaauw, Greyling, \& Kleynhans, 2015). Other studies have argued that graduates from HAI, regardless of race, have better chances of securing employment (Rogan \& Reynolds, 2015). These findings suggest that inequality persists despite the efforts to redress the past imbalances in areas such as health and education. 


\section{Gaps in the literature}

Some gaps exist in the literature. We note three gaps. Firstly, there is a need for an increased understanding regarding student transition into the labour market, especially challenges such as high unemployment (Coetzee \& Schreuder, 2018; Harry et al., 2018; Scott, 2018). Gedye and Beaumont (2018) noted that there appears to be an empirical overlook into the student perceptions on aspects of work readiness and transition into the labour market. Work readiness represents the attributes required by graduates to be successful in the workplace (Chavan \& Carter, 2018). Maree (2018) cautioned that there is a need to consider such transitions as a basis of expanding contemporary understanding on career issues and needed skills concerning employability. Such investigations can assist in providing an expansive understanding of issues faced by individuals in view of challenges (such as unemployment) and a basis for advancing theory. The gap we identify here from the literature appears to magnify the need to give a voice to students and understand the career issues they face. However, we also note a second gap in the literature concerning issues that affect institutions of higher learning in South Africa (Harry et al., 2018).

Institutions of higher learning are tasked with the responsibility of producing human capital. Challenges exist however, as qualifications from such institutions of higher learning are noted as not being a guarantee in producing such capital (Shivoro et al., 2018; Walker \& Fongwa, 2017). The expectation is that as part of university enrolment students are expected to be equipped with the right set of employability attributes (Chinyamurindi, Rukuni, \& Marembo, 2017; Coetzee \& Schreuder, 2018; Shivoro et al., 2018). The reality is the opposite, as institutions of higher learning are criticised for mostly placing emphasis on theoretical knowledge (Council on Higher Education, 2016; Tadesse, Manathunga, \& Gillies, 2018) and in some cases placing little or no emphasis on the community focus and career guidance. This has led to some calling for a re-think into the model of higher learning in South Africa to address the disparities that exist (Fongwa, 2018; Mayaba, Ralarala, \& Angu, 2018) and to become more accountable. Institutions of higher learning need to be asking critical questions regarding how they can enhance graduate employability and reduce the high unemployment figures.

Furthermore, there is a need to ascertain and understand those issues of work readiness and the requisite skills sets needed by the students of institutions of higher learning and their integration into the labour market. Unsurprisingly, because of a lack of skills, graduates are struggling to make the transition into the labour market (Harry et al., 2018). Employment is defined as an individual's status in the labour market (searching for a job or already in a job), whilst employability represents the skills that enable an individual to compete for employment with other job seekers (Rich,
2015). In other words, employability is the skills and attributes required by an individual in order to be employed and successfully perform the duties of a position. An individual can thus be employable but remain unemployed.

The third and final gap is the methodological gap. We note and support the observation by $\mathrm{O}^{\prime} \mathrm{Neil}$ and Koekemoer (2016) that the dominant methods of inquiry within the fields of human resources management (HRM) and industrial and organisational psychology (IOP) to be mostly quantitative in nature rely on surveys as the main method of data collection. There is merit in how the quantitative approach, inclusive of the use of surveys, has aided the understanding of concepts within the HRM and IOP fields. Chinyamurindi (2012) lauds for more qualitative research, especially within the HRM and IOP fields, which is also supported by other scholars (e.g. Harry et al., 2018; Kinnear \& Ruggunan, 2019; O'Neil \& Koekemoer, 2016) as a useful basis for understanding behaviour, especially when working with vulnerable groups and complex life experiences. We seek to answer such calls and illustrate the value of qualitative research through the use of drawings in HRM employability research.

\section{Theoretical postulations}

Different theories and models exist in the literature regarding graduate employability (employment). One notable theory is the human capital theory (Becker, 1964). Emphasis can be placed on the development of 'knowledge, skills and abilities' (Schultz, 1961, p. 140) that are either innate or acquired (Schultz, 1981). Becker (1993, p. 3) extends understanding by framing human capital as consisting of 'knowledge, information, ideas, skills and health of individuals.' Institutions of higher education and training can be useful conduits in the development of these forms of human capital (Donald, Baruch, \& Ashleigh, 2019) in students: (1) social capital, (2) cultural capital and (3) scholastic capital (Useem $\&$ Karabel, 1986). In addition to the human capital theory, we give cadence and focus on the resilience framework.

\section{Resilience framework}

Resilience is explained as a 'positive psychological capacity to rebound, to "bounce back" from adversity, uncertainty, conflict, failure, or even positive change, progress and increased responsibility' (Luthans, 2002, p. 702) and is used to describe how people deal with unemployment (Victor, 2016). A resilience framework thus supported this study. Resilience is adopted as a working concept for this study and viewed as a process (enrolment for higher education studies) and as an outcome (employment) (Chung, Turnbull, \& ChurHansen, 2017). The resilience framework involves being strong in the face of adversity and learning from those hardships (Mayaba \& Wood, 2015; Zulu, 2018). This is important in a country such as South Africa that is characterised by high unemployment rates caused by factors such as racial and social inequality (Harry et al., 2018). Participatory research is thus important in understanding and promoting resilience amongst the youth in the face of 
high unemployment rates. An individual who has resilience traits is highly characterised by traits such as self-confidence, esteem, efficacy and determination that promote the psychological well-being of an individual (Joyce et al., 2018; Theron, 2012).

\section{Research purpose}

The purpose of this study was threefold: (1) to explore the experiences of students in preparation to enter the labour market, (2) to generate data about student experiences of being unemployed and (3) to explore the usefulness of drawings as a data generation tool in exploring such experiences.

\section{Research design and context}

To understand university-to-work transition amongst students leaving the university setting, an interpretivist philosophy was adopted using the qualitative research approach informed by the exploratory research design (Creswell, 2014). This design was adopted to understand university-to-work transition en route to competing in the open labour market. Visual participatory methods are regarded as an innovative research technique (Barley \& Russell, 2018). Using a visual participatory approach provided a context for reflection, social change and action. Furthermore, a visual participatory approach allowed the participants to voice their experiences during their studies (Saunders, 2018). The students' understanding of the concepts of employability and university-to-work transition was enhanced by using such an approach. In addition, a visual participatory approach allowed students to suggest possible solutions to the perceived problems they face.

The study was conducted at a traditional HDI in the Eastern Cape province of South Africa. Qualifications offered by traditional universities are more theoretical with less vocational preparation in contrast to comprehensive universities and universities of technology (Magagula, 2017). Graduates from HDIs struggle in the open labour market as compared to graduates from HAIs (Rogan \& Reynolds, 2016; South African Department of Higher Education and Training, 2018). Hence, there is the need to understand university-to-work transition. This is because inequality in South Africa remains a great problem (Khau, 2018; Motala, 2017). A total of 30 students, who were in their final year of undergraduate studies in the Department of Business Management, participated in this study. The sample was gathered using a combination of purposive and convenience sampling methods (Creswell, 2014). In this regard, participants had to be final-year undergraduate students from the HDI to participate in the study.

\section{How drawings were used to generate data?}

Several studies (e.g. Barley \& Russell, 2018; Isseri, Muthukrishna, \& Philpott, 2018; Mayaba \& Wood, 2015) have utilised drawings as a data collection method. As in the study by Mayaba and Wood (2015, p. 3), we adopted a 'draw and write' approach. This approach, as advocated by Mair and Kierans (2007), allows participants to elaborate on the meaning of the drawing through oral and written explanations. This method was selected as some of the participants had limited English language abilities (Mayaba \& Wood, 2015). During this study, drawings, together with written explanations, therefore allowed the participants to express themselves. An email was sent to all the students who were in their final year of study to participate in the study. Potential participants were invited to take part in the research through a focus group at a designated date and time slot.

Before the commencement of the focus group, the participants were briefed about the purpose of the study. All the groups were given an A3 paper in which they were to draw their perceptions of their work readiness. To elicit drawings, the following question was posed: can you draw a picture that describes your feelings of work readiness as you are about to enter the world of work? Participants were encouraged to draw anything that would describe their feelings towards university-to-work transition. How well the drawing looked was not of importance. This allowed the participants to share their views on employability and suggest possible solutions to reduce the graduate unemployment rate. As drawing the picture was a group activity, the members of the groups were asked to write a phrase that described their feelings. After the drawing activity, the groups were invited to explain their drawings.

All the focus group participants were invited to share their thoughts on the other groups' drawings. The credibility of the study was enhanced by describing the drawings comprehensively, literature control (focus on the literature that was relevant for this study), sharing of the meaning and data retention. The session produced lively discussions; although the students felt they were not work-ready, there was a mutual feeling of soldering on to become relevant to the labour market.

\section{Ethical consideration}

The researchers adhered to ethical guidelines in conducting the study. Ethical clearance was obtained from the participating institution (reference number: CHI151SHAR01). Participation in the study was on a voluntary basis and a signed written informed consent was a prerequisite before participation. Anonymity and confidentiality were guaranteed.

\section{Data analysis}

As was proposed by Miles and Huberman (1994), three flows of activity were adopted to analyse the qualitative data. These three flows of activity process have also been used in previous empirical works (e.g. Makhene, 2019; Ogbamichael \& Warden, 2018), attesting to the robustness of the process. The process involves data reduction, data display and conclusion. Data reduction was done at the begining and during the data collection process. Whilst 
engaged in speculation, the researchers and the participants reflected on the literature whilst searching for meaning within the drawings. The researchers were able to make new interpretations and ask prompting questions through being speculative. Furthermore, the researchers and the participants were able to search for themes to illustrate the full picture. To understand the concepts of employability and work readiness, the drawings should be viewed as a starting point for personal thought development and experiences of the concepts. The activity allowed the participants to eloquently communicate and reflect their understanding of the concepts of employability and work readiness through the drawings. The drawings also allowed the researchers to explore the experiences of students as they prepare to enter the labour market, including the experience of being unemployed.

\section{Findings}

University-to-work transition is affected by various factors, such as trends of the labour market and higher education institution. Hence, it is necessary for students to have the knowledge and understanding of the concepts to come up with possible solutions to enhance their employment in the labour market. Many stakeholders in the labour market are of the perception that higher education universities are responsible for producing work-ready graduates. Participants were, however, underprepared for the world of work despite being in their final year of studies. Three main narratives emerge, which form the basis of the discussion being made in this article. The pictures, together with the explanations, reflect that the participants were not ready to be competitive.

\section{Narrative finding 1: Blind but determined}

The picture that was drawn by Group 1 (Figure 1) shows that although studying for a tertiary qualification, the students in their view state that they remain 'blind' as their qualifications only focused on enhancing theoretical expertise with less practical relevance.

Furthermore, students were at a crossroads in their lives despite having the 'right qualifications.' The road is clear with no obstacles, meaning that they have all the required qualifications but still feel 'confused and lost' because of a lack of work experience. Participants also experienced periods of difficulty stemming from their families who wanted an alternative path. One of the participants said, (Participant 5, 27 years old, male) 'my family is giving me pressure and friends who studied at colleges who did practical work to get a job, but I am stuck with theory.' Because of the above reasons, many of the participants struggled to make a smooth transition into the labour market.

The same perception was also shared by Group 2 as shown in Figure 2.

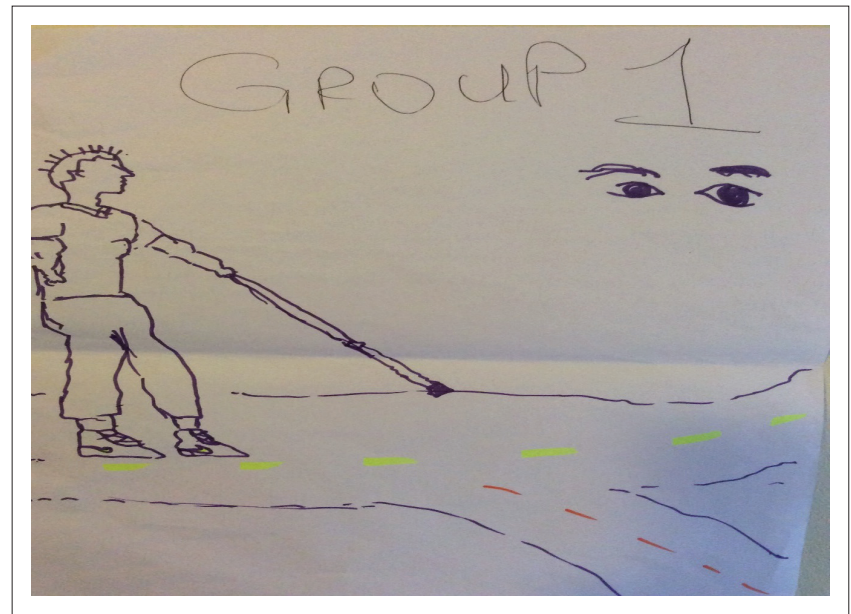

Source: Photo was taken by authors

FIGURE 1: Blind but determined.

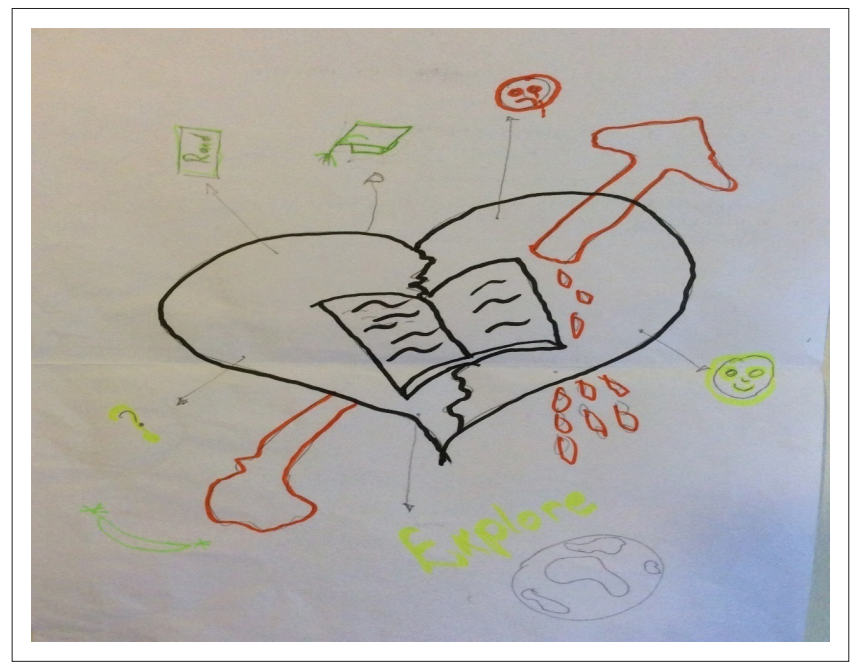

Source: Photo was taken by authors

FIGURE 2: Excited but scared.

\section{Narrative finding 2: Excited but scared}

The participants indicated that they were heartbroken by the prospect of not securing jobs because of lack of work experience:

'[I]t breaks my heart to spend sleepless nights and at the end of the day I am asked for the experience which I do not have but I only have my qualification.' (Participant 7, 25 years old, female)

Furthermore, the heart is bleeding reflecting the passion for studying, yet it leads to no job. This reveals that despite having their qualifications, they feared being 'undermined' by other students from other universities. The qualifications were being undermined because of the institutions they had obtained the qualifications from.

Despite the confusion and lack of work experience, some of the participants in the groups felt 'encouraged' and a step 'closer to getting a job than yesterday.' The qualification they were about to attain was going to allow them to 'explore the world.' 


\section{Narrative finding 3: Ready to explore}

A similar view was expressed in Groups 2 and 3 in which participants notes that theu were ready for the world of work (see Figure 3).

Regardless of the lack of work experience, the group participants felt that they were ready to 'take on the world.' The programmes that they were studying made them feel 'empowered and confident' to secure jobs. This is shown by the picture (Figure 3) they drew of a graduate who had the whole world to explore without any limitations.

During the discussion, many of the participants revealed that they had an inferiority complex. The inferiority complex was not only experienced when they tried to approach the lecturers, it was also experienced in their approach to the labour market. The participants felt inferior when interacting with their lecturers to gain more information about the labour market. The inferiority complex situation was clearly elaborated by one of the participants, who stated that:

'[I] feel that I will not be able to compete in the labour market because there are other students who are from advanced institutions (white institutions) who can do better.' (Participant 10, 28 years old, female).

This perception developed as a result of where these participants came from, that is, previously disadvantaged backgrounds. Subsequently, the participants did not have confidence in themselves.

Furthermore, the location of the university was a restriction to the career development of the students. The university is located in a rural area; hence, the participants were not well versed in the market trends. They ended up relying on the Internet for information and, because of the inferiority complex, they were unable to communicate with their lecturers for job market information. Because of the university location, they felt that they were not ready to be competitive as compared to their counterparts in urban universities. Furthermore, the participants were of the perception that the knowledge acquired at HAIs was more superior to that

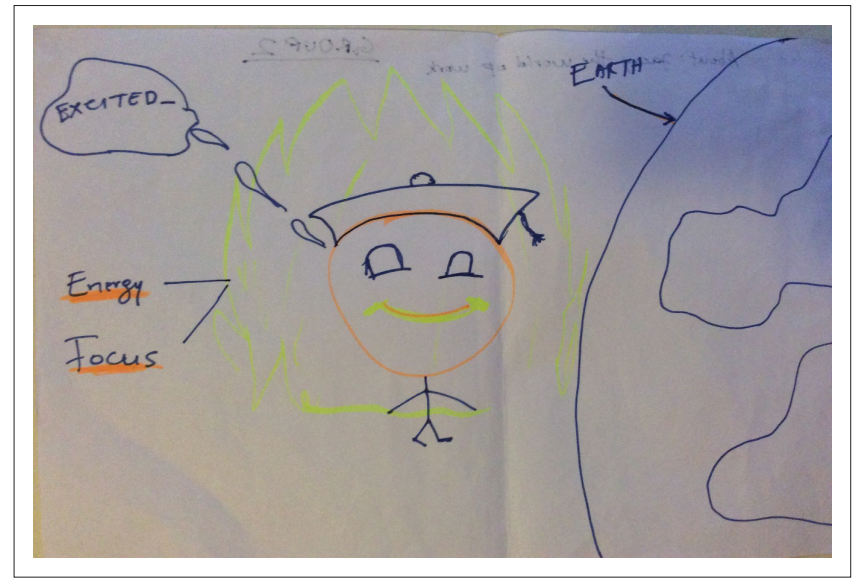

Source: Photo was taken by authors

FIGURE 3: Ready to explore. gained from an HDI. Another point that was noted is that the participants lacked knowledge of their careers. They had not received adequate career guidance and counselling.

Many of the participants in the three groups highlighted a lack of work experience as their main concern. Without work experience, they described themselves as 'confused and lost', not knowing what to do. Furthermore, the socio-economic status of the families was exerting much 'pressure' on the participants to get employment soon after completion of their studies. In response to the pressure from friends and families, the participants explained that because of a lack of work experience, most of them will enrol for a Post-Graduate Certificate in Education (PGCE). The predicament was expressed by one of the participants as follows:

' $[W]$ e are from poor family backgrounds but due to a lack of work experience and pressure from the family to provide, we end up enrolling for PGCE as it offers both theory and practical sides (which is not available for commerce programmes). With a PGCE we will have many opportunities plus it is easier to get employment.' (Participant 10, 28 years old, female).

The lack of the practical aspect in the commerce degrees was a limiting factor in their competitiveness. Family socioeconomic status was the major determinant indicating what the participants will do to secure jobs.

In addition, it was further highlighted in the explanations that because of a lack of social networks, the students were deprived of opportunities to develop themselves. The participants mentioned that students from HAIs had all the resources they needed to be successful in their careers, but HDIs had very limited resources. With limited resources, the participants felt that their chances of obtaining jobs were also limited. During the discussion, one of the participants stated that (Participant 10, 28 years old, female) 'resources and opportunities are available in South Africa, but it is difficult to get them as one needs connections to be able to benefit from them.'

Because of the unavailability of practical knowledge for commerce programmes, participants were taking responsibility of ensuring their work readiness and employability. Vacation work was the most common way to enhance one's work readiness and employability. Vacation work is viewed as a way to gain work experience. One of the participants espoused that (Participant 10, 28 years old, female) 'I took up vacation work in a pharmacy as a sales representative, and during that time I managed to learn how to interact with other people.' This shows that vacation work is a way of developing generic skills, such as interaction skills and relationship building, to enhance one's employability. Some participants said that they did volunteer work such as assisting in shops when on holidays. Many of the participants mentioned that they were applying for various internships to gain work experience, such as the National Research Foundation Internship Programme and internships in various government departments. Unfortunately, they were not getting a positive response. 


\section{Discussion}

Many of these participants enrolled for higher education in the hope of securing employment upon graduation. However, the study findings indicate that the participants had chosen their programmes without adequate career counselling and guidance. Unsurprisingly, the participants lacked the necessary information about the qualifications they were pursuing. As mentioned in previous studies (e.g. Magagula, 2017; Rogan \& Reynolds, 2016), the South African basic education system is of a poor standard. As a result, many underprepared students are entering the higher education system. Students who are not educated well in school struggle to succeed at the university level. Undoubtedly, it is mostly black students who are underprepared for higher education because of the dysfunctional schooling left by the apartheid legacy and the continued failure of current governance structures.

Another important finding was that the university programmes lacked a practical component in their curriculum. Consequently, the students were unprepared for the world of work. The students lacked the relevant skills to compete in the labour market. A lack of the practical side of the programmes limits the participants' chances of obtaining work experience. Therefore, there is a need to develop curricula that are balanced between theory and practice. These findings further support the idea of revising curricula to include a practical component (Council on Higher Education, 2016; Tadesse et al., 2018). Employers are looking for candidates who have skills that can be transferred into the company for the benefit of the company.

The participants appeared to have a lack of confidence in themselves and their qualifications. A possible explanation for this is the perception towards HDI degrees. Employers prefer graduates from HAIs as their qualifications are regarded as superior to the HDIs degrees. These findings are consistent with previous studies (e.g. Magagula, 2017; Rogan \& Reynolds, 2016; Scott, 2018). The participants therefore felt inferior in comparison to their counterparts who qualified through HAIs. Being inferior was further exacerbated by the race of the participants and being the first people to attend higher education within their families did not make it easy.

Moreover, because of a lack of social capital, participants struggled to make the transition into the open labour market. In addition, this finding supports Rogan and Reynolds's (2016) study in which they argued that students from HDIs had weaker social networks. Participants of this study were relying on traditional and formal ways to apply for employment (Rogan \& Reynolds, 2016). Such differences show that, despite efforts to redress past imbalances, inequality remains a major concern in education and in the labour market of the country (Fox et al., 2016).

Irrespective of several adversities, the students had the desire of securing employment in the future (Mayaba \& Wood, 2015).
However, unlike Joyce et al. (2018), the findings indicate that although resilient, participants lacked traits such as selfconfidence, efficacy and esteem; this was mainly because of their previously disadvantaged backgrounds. Theron (2012) pointed out that resilience could be promoted through factors such as social capital, problem-solving skills and opportunity for mastery. However, the findings of this study indicate that most participants lacked these skills to promote resilience in the context of high unemployment amongst black graduates.

\section{Practical implications}

Employers are increasingly demanding graduates who are ready to work. A mere qualification is therefore not enough to secure an employment because of the present economic status that requires employees to contribute efficiently and effectively to the organisation soon after being hired. Subsequently, employers are in high demand of graduates who are work-ready. Hence, students must be equipped with generic and specific skills, as well as work readiness programmes and workplace experience, to be competitive in the job market. Employers thus postulate that such skills should be developed during the students' higher education process.

However, higher education institutions are failing to meet the skills demands of the labour market. In view of that, students are trying to make it their responsibility to be workready through seeking opportunities for skills development in order to be competitive in the job market. However, such endeavours are limited and affected by the geographical location, failing government support structures and limited resources that inhibit students from exploring the labour market.

Higher education institutions need to continue developing their curricula to develop graduate work readiness attributes. Although curriculum change will help address the skills gap, it is not the solution for graduate unemployment, especially for graduates from HDIs. Unemployment of HDI graduates is mainly caused by perceived degree quality, underpreparedness of students for higher education, a lack of social and professional networks, as well as perceived discrimination in recruitment. Therefore, there is a need for businesses, government and universities to collaboratively redress the racial imbalances in the country by working together to create opportunities, especially for the previously disadvantaged students. Developments and changes without addressing inequality will not yield sustainably positive results. Perhaps, black graduates require assistance from different stakeholders to be able to compete in the labour market.

Furthermore, universities cannot work alone in developing work-ready students. Thus, the industry should increase their involvement in preparing students for the job market. This can be done by recruiting students for work readiness programmes. Hence, it is imperative that universities and 
potential employers collaborate in developing work-ready graduates. Employers are consistently demanding highly educated and skilled employees. A co-operation thus between employers and universities will lead to the economic development of the country.

Moreover, for the economic development of South Africa, the importance of commerce degrees cannot be denied. Hence, the claim that HDI graduates enrol in programmes that have poor employment prospects is false. Labour market outcomes for these students can be achieved by improving the quality of school education, higher socio-economic status and establishing social and professional networks as advocated by Rogan and Reynolds (2016).

\section{Limitations of the study and future research areas}

The sample size was a limitation of this study as only a few drawings were presented. Furthermore, people are storytellers and hence drawings might have been a restriction; however, the limitation was minimised by having the group to discuss the meaning denoted by the picture. Socially acceptable behaviour could have been a limitation as the activity was done in groups. Moreover, the study was limited to final-year undergraduate students at one university in one faculty. Hence, the results cannot be generalised to other faculties or institutions. It was necessary to limit the study to the Faculty of Management and Commerce because of lack of practical aspect of programmes.

Although graduates enter the job market without relevant skills, it is also important to understand work readiness from the perspective of the employer to gain an insight into how the challenges can be overcome and what the organisational expectations are. Furthermore, future studies should focus on the perceived mismatch between graduates and job market skills. In addition, future research should include students across faculties, not only to increase the sample size but also to increase the generalisation of study results.

\section{Conclusion}

This study provided valuable understanding into the work readiness of final-year students from a selected university in South Africa. The economic development of a nation depends on well-equipped graduates. For historically disadvantaged students to succeed, South African higher education institutions are responsible for developing academic excellence, and providing specific and generic business skills. Furthermore, it is the responsibility of the institutions and employers to have the students work-ready by increasing employability skills. The study concludes that the students lack generic skills in order to be competitive in the job market. Hence, higher education institutions have an important role to increase the work readiness of students. Interventions should be made to address the unemployment rates and causes of unemployment amongst graduates from HDIs.

\section{Acknowledgements Competing interests}

The authors have declared that no competing interest exists.

\section{Authors' contributions}

W.T.C. supervised T.H. for his PhD degree. The article was a joint effort between the supervisor and the student.

\section{Funding information}

The authors acknowledge with appreciation the financial assistance of the National Research Foundation's Competitive Support for Unrated Researchers (Grant Number: 114380) and also the funding provided by the National Institute for the Humanities and Social Sciences for African Pathway trips to Uganda and Zambia where versions of this article were presented. Financial support from these funders helped in revising and subsequently producing this work.

\section{Data availability statement}

Data sharing is not applicable to this article as no new data were created or analysed in this study.

\section{Disclaimer}

The views and opinions expressed in this article are those of the authors and do not necessarily reflect the official policy or position of any affiliated agency of the authors.

\section{References}

Aida, B., Norailis, A.W., \& Rozaini, R. (2015). Critical success factors of graduate employability programmes. Journal of Economics, Business and Management 3(8), 767-771. https://doi.org/10.7763/JOEBM.2015.V3.283

Baldry, K. (2016). Graduate unemployment in South Africa: Social inequality reproduced. Journal of Education and Work, 29(7), 788-812.

Barley, R., \& Russell, L. (2018). Participatory visual methods: Exploring young people's identities, hopes and feelings. Ethnography and Education, 14(2), 223-241. https://doi.org/10.1080/17457823.2018.1441041

Becker, G. (1964). Human capital (2nd edn.). New York, NY: Columbia University Press.

Becker, G. (1993). The economic way of looking at behavior. Journal of Political Economy, 101(3), 385-409.

Bhorat, H., Mayet, N., \& Visser, M. (2010). Student graduation, labour market destinations and employment earnings. In: M. Letseka, M. Cosser, M. Breier, \& M. Visser (Eds.), Student retention \& graduate destination: Higher education \& labour market access \& success (pp. 97-124). Cape Town: HSRC Press.

Branson, N., De Lannoy, A., \& Brynde, K. (2019). Review of youth labour market research. Retrieved from http://www.opensaldru.uct.ac.za/handle/11090/948

Chavan, M., \& Carter, L. (2018). Management students - Expectations and perceptions on work readiness. International Journal of Educational Management, 32(5) 825-850. https://doi.org/10.1108/IJEM-10-2016-0219

Chinyamurindi, W.T. (2012). Stories of career change amongst distance learners in South Africa. South African Journal of Human Resource Management, 10(2), 1-11.

Chinyamurindi, W.T. (2016). Using narrative analysis to understand factors influencing career choice amongst a sample of distance learning students in South Africa. South African Journal of Psychology, 46(3), 390-400. https://doi.org/10.1177/00 81246315623662

Chinyamurindi, W.T., Rukuni, N., \& Marembo, M. (2017). The relationship between self-esteem and employability attributes: An empirical investigation at an institution of higher learning in South Africa. 29th Southern Africa Institute for Management Scientists (SAIMS), Annual Conference Proceedings.

Chung, E., Turnbull, D., \& Chur-Hansen, A. (2017). Differences in resilience between 'traditional' and 'non-traditional' university students. Active Learning in Higher Education, 18(1) 77-87. https://doi.org/10.1177/1469787417693493 
Creswell, J.W. (2014). Research design, qualitative and quantitative and mixed methods approaches (4th edn.). London: Sage.

Coetzee, M., \& Schreuder, D. (2018). Proactive career self-management: Exploring links among psychosocial career attributes and adaptability resources. South African Journal of Psychology, 48(2) 206-218. https://doi.org/10.1177/008124 6317719646

Council on Higher Education. (2016). South African higher education reviewed: Two decades of democracy. Pretoria: Council on Higher Education.

Dunga, S.H. (2016). An explanatory study of the variation in unemployment length of graduates of different degree programs. International Business \& Economics Research Journal, 15(2), 69-78. https://doi.org/10.19030/iber.v15i2.9636

Donald, W.E., Baruch, Y., \& Ashleigh, M. (2019). The undergraduate self-perception of employability: Human capital, careers advice, and career ownership. Studies in Higher Education, 44(4), 599-614. https://doi.org/10.1080/03075079.2017. 1387107

Fongwa, S. (2018). Towards an expanded discourse on graduate outcomes in South Africa. Education as Change, 22(3), 1-23. https://doi.org/10.25159/1947$9417 / 3337$

Fox, L., Senbet, L.W., \& Simbanegavi, W. (2016). Youth employment in Sub-Saharan Africa: Challenges, constraints and opportunities. Journal of African Economies, 25(1), 3-15. https://doi.org/10.1093/jae/ejv027

Frick, L. (2018). Next Gen PhD: A guide to career paths in science. Higher Education Research \& Development, 37(1), 222-224.

Gedye, S., \& Beaumont, E. (2018). 'The ability to get a job': Student understandings and definitions of employability. Education + Training, 60(5), 406-420. https:// and definitions of employability. Edu
doi.org/10.1108/ET-10-2017-0159

Graham, L., \& De Lennoy, A. (2016). Youth unemployment: What can we do in the short run? Retrieved from http://www.econ3×3.org/article/youth-unemploymentwhat-can-we-do-short-run.

Graham, L., Williams, L., \& Chisoro, C. (2019). Barriers to the labour market for unemployed graduates in South Africa. Journal of Education and Work, 32(4), 360-376. https://doi.org/10.1080/13639080.2019.1620924

Harry, T., Chinyamurindi, W.T., \& Mjoli, T. (2018). Perceptions of factors that affect employability amongst a sample of final-year students at a rural South African university. South African Journal of Industrial Psychology, 44(6), 1-10. https://doi. org/10.4102/sajip.v44i0.1510

Henderson, J.L., Hawke, L.D., \& Chaim, G. (2017). Not in employment, education or training: Mental health, substance use, and disengagement in a multi-sectoral sample of service-seeking Canadian youth. Children and Youth Services Review, $75,138-145$.

Irwin, S., Mader, P., \& Flynn, J. (2018). How youth-specific is Africa's youth employment challenge? K4D emerging issues report. Brighton: Institute of Development Studies.

Isseri, S., Muthukrishna, N., \& Philpott, S.C. (2018). Immigrant children's geographies of schooling experiences in South Africa. Educational Research for Social Change, 7(2) 39-56. https://doi.org/10.17159/2221-4070/2018/v7i2a3

Joyce, S., Shand, F., Tighe, J., Laurent, S.J., Bryant, R.A., \& Harvey, S.B. (2018). Road to resilience: A systematic review and meta-analysis of resilience training programmes and interventions. BMJ Open, 8(6), 1-9. https://doi.org/10.1136/ bmjopen-2017-017858

Khau, M. (2018). Editorial. Educational Research for Social Change, 7(2), vii-x.

Kinnear, L.C., \& Ruggunan, S. (2019). Applying duoethnography to position researcher identity in management research. South African Journal of Human Resource Management, 17(1), 1-11. https://doi.org/10.4102/sajhrm.v17i0.1056

Kraak, A. (2010). The collapse of the graduate labour market in South Africa: Evidence from recent studies. Research in Post-Compulsory Education, 15(1) 81-102.

Lourens, E. (2016). From graduate to employee: Exploring the journeys of first-time entrants into the labour market. Unpublished doctoral dissertation, Stellenbosch University, Cape Town

Luthans, F. (2002). The need for and meaning of positive organizational behaviour. Journal of Organizational Behavior, 23(6), 695-706. https://doi.org/10.1002/ job.165

Magagula, B. (2017). An exploration into the social support systems of unemployed graduates. Masters dissertation. Pretoria, South Africa. Retrieved from http://hdl. handle.net/10500/23303

Mair, M., \& Kierans, C. (2007). Descriptions as data: Developing techniques to elicit descriptive materials in social research. Visual Studies, 22(2), 120-136. https:// doi.org/10.1080/14725860701507057

Makhene, A. (2019). The use of the Socratic inquiry to facilitate critical thinking in nursing education. Health SA Gesondheid, 24(1), 1-6. https://doi.org/10.4102/ hsag.v24i0.1224

Maree, J.G. (2018). Advancing career counselling research and practice using a novel quantitative+qualitative approach to elicit clients' advice from within. South African Journal of Higher Education, 32(4) 149-170. https://doi.org/10.20853/ 32-4-2558

Mayaba, N.N., Ralarala, M., \& Angu, P. (2018). Student voice: Perspectives on language and critical pedagogy in South African higher education. Educational Research for Social Change, 7(1), 1-12. https://doi.org/10.17159/2221-4070/ 2018/v7i1a1

Mayaba, N.N., \& Wood, L. (2015). Using drawings and collages as data generation methods with children: Definitely not child's play. International Journal of Qualitative Methods, 14(5), 1-10. https://doi.org/10.1177/1609406915621407
Miles, M.B., \& Huberman, A.M. (1994). Qualitative data analysis an expanded sourcebook. Thousand Oaks, CA: Sage.

Mok, K.A. (2016). Massifying and internationalising higher education, changing labour markets and social mobility: Challenges for education and urban governance. Journal of Higher Education Policy and Management, 38(3), 233-241. https://doi. org/10.1080/1360080X.2016.1174402

Motala, S. (2017). Introduction - Part III Achieving 'free education' for the poor - A realisable goal in 2018? Journal of Education, 68(1), 15-29.

Musitha, M., \& Mafukata, M. (2018). Crisis of decolonising education: Curriculum implementation in Limpopo Province of South Africa. Africa's Public Service Delivery and Performance Review, 6(1), 1-8. https://doi.org/10.4102/apsdpr.v6i1.179

Mncayi, P., \& Dunga, S.H. (2016). Career choice and unemployment: A study from a South African university. Industry and Higher Education, 30(6), 413-423.

Ogbamichael, H.B., \& Warden, S. (2018). Information and knowledge sharing within virtual communities of practice. South African Journal of Information Management, 20(1), 1-11. https://doi.org/10.4102/sajim.v20i1.956

Oluwajodu, F., Blaauw, D., Greyling, L., \& Kleynhans, E.P.J. (2015). Graduate unemployment in South Africa: Perspectives from the banking sector. South African Journal of Human Resource Management, 13(1), 1-9. https://doi. African Journal of Human Resc
org/10.4102/sajhrm.v13i1.656

O'Neil, S., \& Koekemoer, E. (2016). Two decades of qualitative research in psychology, industrial and organisational psychology and human resource management within South Africa: A critical review. South African Journal of Industrial within South Africa: A critical review. South African Journal
Psychology, 42(1), 1-16. https://doi.org/10.4102/sajip.v42i1.1350

Pauw, K., Oosthuizen, M., \& Van der Westhuizen, C. (2008). Graduate unemployment in the face of skills shortages: A labour market paradox. South African Journal of Economics, 76(1), 45-57.

Reddy, V. (2016). Skills supply \& demand for South Africa. Accept AE: Labour Market Intelligence Partnerships (LMIP).

Rich, J. (2015). We need to talk about employability, not employment. Times Higher Education, 10 December, pp. 24-25.

Rogan, M., \& Reynolds, J. (2016). Schooling inequality, higher education and the labour market: Evidence from a graduate tracer study in the Eastern Cape, South Africa. Development Southern Africa, 33(3), 343-360.

Rogan, M., \& Reynolds, J. (2016). Study choices and employment transitions among Rhodes Fort Hare university graduates. Human Sciences Research Council, Media Release. Retrieved from http://www.hsrc.ac.za/en/news/view/study-choices.

Saunders, A. (2018). Seeing visuals through a unique lens: A review of participatory visual methodologies: Social change, community, and policy. The Qualitative Report, 23(5), 1101-1103.

Scott, I. (2018). Designing the South African higher education system for student success. Journal of Student Affairs in Africa, 6(1), 1-17. https://doi.org/10.24085/ jsaa.v6i1.3062

Schoër, V., Rankin, N., \& Roberts, G. (2014). Accessing the first job in a slack labour market: Job matching in South Africa. Journal of International Development, 26(1), 1-22. https://doi.org/10.1002/jid.2838

Schultz, T.W. (1961). Investment in human capital. American Economic Review, 51(1), $1-17$.

Schultz, T.W. (1981). Economics of population. Reading, MA: Addison-Wesley.

Shivoro, R. S., Shalyefu, R.K., \& Kadhila, N. (2018). Perspectives on graduate employability attributes for management science students. South African Journal of Higher Education, 32(1), 216-232. https://doi.org/10.20853/32-1-1578

South African Department of Higher Education and Training (DHET). (2018). The 4th annual research colloquium: Enhancing the implementation of the South African NQF: Colloquium proceedings. Pretoria: Department of Higher Education and Training.

Statistics South Africa. (2019). Unemployment rises slightly in third quarter of 2019. Retrieved from http://www.statssa.gov.za/publications/P0211/P02113rdQuarter 2019.pdf.

Tadesse, T., Manathunga, C.E., \& Gillies, R.M. (2018). Making sense of quality teaching and learning in higher education in Ethiopia: Unfolding existing realities for future promises. Journal of University Teaching \& Learning Practice, 15(1) 1-20.

Theron, L.C. (2012). Does visual participatory research have resilience-promoting value? Teacher experiences of generating and interpreting drawings. South African Journal of Education, 32(4), 381-392. https://doi.org/10.15700/saje.v32n4a656

Tomlinson, M., \& Holmes, L. (2017). Graduate employability in context: Theory, research and debate (1st edn.). London: Palgrave Macmillan.

Useem, M., \& Karabel, J. (1986). Pathways to top corporate management. American Sociological Review, 51(2), 184-200. https://doi.org/10.2307/2095515

Van der Berg, S., \& Van Broekhuizen, H. (2012). Graduate unemployment in South Africa A much exaggerated problem. Stellenbosch Economic Working Papers No. 22/12.

Van der Berg, S., Van Broekhuizen, H. \& Hofmeyr, H. (2016). Higher education access and outcomes for the 2008 national Matric cohort. Stellenbosch Economic Working Papers No.16.

Van de Rheede, T.J. (2012). Graduate unemployment in South Africa: Extent, nature and causes. Masters Dissertation. University of Western Cape. Master of Commerce in the Department of Economics.

Victor, P.E. (2016). Unemployment and resilience: The role of optimism in the perception of lack of health. A work project presented as part of the requirements for the award of a Master Degree in Management from the NOVA - School of Business and Economics. Retrieved from https://run.unl.pt/bitstream/10362/ 19339/1/Victor_2016.pdf. 
Von Möllendorff, M., Kurgat, S., \& Speck, K. (2017). East and South African-German centre of excellence for educational research methodologies and management Educational Research for Social Change, 6(1), 93-99.

Wakelin-Theron, N., Ukpere, W.I., \& Spowart, J. (2018). Perception of tourism graduates and the tourism industry on the important knowledge and skills required in the tourism industry. African Journal of Hospitality, Tourism and Leisure, 7(4), 1-18.
Walker, M., \& Fongwa, S. (2017). Universities, employability and human development. London: Palgrave Macmillan.

Walton, E. (2018). Decolonising (through) inclusive education? Educational Research for Social Change, 7(1), 31-45.

Zulu, N.T. (2018). Resilience in Black women who do not have fathers: A qualitative inquiry. South African Journal of Psychology, 49(2) 1-10. https://doi.org/10. $1177 / 0081246318782187$ 